\title{
New Intimates
}

\author{
Paula Kommoss
}

At a time when the world is increasingly interconnected and communication is initiated through digital technology, the nature of intimacy is changing accordingly. In order to stay in touch, many people are dependent on virtual forms of communication. Through these platforms, an interface between physical presence and virtual reality emerges, where users can access digitally rendered bodies that come-visually-astonishingly close to real life. Here, online means confuse the limits of bodily and digital identity. Thus, the notion of touch can be extended into the digital realm, while still often grounded in the phenomenological perception of the self. Its sense may change from the corporeal to a dispersed touch, which takes shape in communicative-verbal or written-expressions of desire for bodies or objects to which we are close, but yet not quite able to physically grasp. The importance of the written word, upon which a great amount of online communication is based, remains persistent. Virtual communication methodologies not only connect people with each other, but more importantly, with themselves.

These phenomena become evident when looking at aesthetic strategies in contemporary artistic practices. This will be discussed, first, through a

P. Kommoss $(\varangle)$

Hochschule für Bildende Künste-Städelschule, Frankfurt am Main, Germany e-mail: paula.kommoss@staedelschule.de

(C) The Author(s) 2021

K. Tavin et al. (eds.), Post-Digital, Post-Internet Art and Education, Palgrave Studies in Educational Futures, https://doi.org/10.1007/978-3-030-73770-2_9 
careful examination of how online communication has been influenced by a physical anonymity and virtual intimacy through. The writing of Hito Steyerl. Further the work of Frances Stark, will give insights into online relationships. Here, there will be a focus on the bodily impacts of online relationships, especially when in front of a screen by oneself. Then, a closer look at the artistic work of Ed Atkins will consider the transfer of physicality to virtual reality, and how this draws one back to one's own perception of the body. Further, the workshops of the educational duo soppa\&bleck will offer an insight into art education's approach toward the digital and thus intimacy. In this way, this essay will consider not only the ways that the intimate becomes apparent online, but also how these outputs channel back to one's own physicality.

\section{Physical Anonymity/Virtual Intimacy}

Online communication has been influenced paradoxically by simultaneous physical anonymity and virtual intimacy. As online forms of communication become ever more prominent in our lives, this paradox is a key prism through which to understand current artistic practices. This becomes evident in the aesthetic appearance of works of art, which are also inevitably influenced by their relationship to societies subsumed by technologies. Here, the notion of post-internet art becomes particularly pertinent. The subtle evocation of touch in the digital era leads us to reinvestigate the notion of intimacy. In an online interview in 2012, the philosopher Byung-Chul Han discussed the implications of the omnipresence of screens for human interaction:

Today, we only touch screens. That way we might unlearn to caress each other [laughs] I think nowadays we're too self-absorbed and that we're not directed towards each other. Depression comes from this self-absorption, and Eros is the experience that tears me out of myself. ${ }^{l}$ (Kapitale Berlin, 2012, trans. Kommoss)

Based on the assumption that the nature of physical human interaction is changing in a society increasingly dependent on virtual communication, Han denounced the screen as a buffer for real touch. However, the screen does not only function as a barrier to "real" touch, but can also open up new modes of intimacy and ways to connect with each other. 
Recurring questions within current artistic debates further focus on how intimacy can be renegotiated and represented within the disembodied space of new technologies that give rise to these surrogate channels for physical interaction. Many artists have incorporated the digital into their artistic practice, such as Lorna Mills' work Ways of Something (2015), with its buzzing collages of animation and GIFs that reflect on the speed, narration, and aesthetic of digital culture. In Ryan Trecartin's high-speed multi-channel videos and room-encompassing installations (for example, Site Visit [2014]), identity and the complexity and interaction of communication in the digital is addressed. Furthermore, through the transcription and animation of digital chat scripts, Frances Stark's $M y$ Best Thing (2011) investigates the physical boundaries of intimate relationships online. Additionally, by the means of digitally rendered imagery in Us Dead Talk Love (2012), Ed Atkins addresses the notion of love beyond the physicality of the body. One may see from these examples that a precise definition of intimacy in the post-digital age represents a persistent challenge, since its occurrence can range from various modes of interpersonal interactions to narcissistic online self-representations.

\section{Digital Intimacy Through Contemporary Art}

As stated above, the ways in which intimacy is addressed by artists nowadays vary greatly in material, form, and content. As illustrated by sociologist Nancy Baym in her book on contemporary online dating-websites such as Tinder, Grindr, and other social networks, Personal Connections in the Digital Age: Digital Media and Society Series (2010), virtual exchange precedes physical encounter. The changing nature of emotions in personal relationships which are dependent on the digital communication revolution is also highlighted by artist Hito Steyerl's 2011 essay, Epistolary Affect and Romance Scams: Letter from an Unknown Woman*. Steyerl investigates the effects of computer-based communication through the increasingly prevalent phenomenon of online scamming. The artist's enquiry is based on the true story of Fred and Esperanza, a couple who met online and regularly exchanged texts over several months, but never met in real life. After some failed attempts to arrange an actual encounter, Fred is informed of Esperanza's death and subsequently transfers money for her cremation to an anonymous account. Even when he finds out that he has fallen victim of organized fraud, his emotional connection to Esperanza hardly changes. Steyerl (2011) uses the example of Fred and 
Esperanza to illustrate the ways in which online communication permeates current modes of social interaction, thus affecting the manner in which intimate relationships are formed.

Online encounters and relationships are already a vital part of contemporary daily life: "This is not science-fiction; it's an awkwardly developing truth - one that, over the next generations, will necessitate social scientists and cultural producers to demarcate how intimacy happens over screens" (McHugh, 2014, p. 34). Evidently, there has been significant growth in the number of human relationships generated by online platforms such as dating websites, and more recently, dating apps. These tools allow for a virtual encounter that precedes a physical one, and, as in the case of Fred, can even lead to a virtual relationship that seems no less real than a bodily one. Affirming this in her essay, Steyerl (2011) claims that the absence of the physical body is an inevitable, but not negative, outcome of online communication. She writes that a

live and lively absence, to which the lack of a physical body is not an unfortunate coincidence, but necessary. Its proxy is compressed as message body, translated into rhythm, flow, sounds, and the temporality of both interruption and availability. None of this is 'virtual' or 'simulated.' The absence is real, just as is the communication based on it. (pp. 58-59)

For Steyerl, online communication remains a feasible mode entirely through the live and lively absence of the body. That is, only the internalized account of disembodied reality generates true communication online. It might be a loss of the physical body, but offers further possibilities of intimacy.

French philosopher Jean Baudrillard's publication, Why Hasn't Everything Already Disappeared? (2009), is similarly concerned with the notion of disappearance in our digitalized, disembodied age. Baudrillard examines the disappearance of the real in times of virtual realities. He stresses that this disappearance is not solely based on "the virtual transmutation of things, of the mise en abyme, but that of the division of the subject to infinity, of a special pulverization of consciousness into all the interstices of reality" (Baudrillard, 2009, p. 19). This so-called pulverization evokes the merging of our consciousness with the world itself, and makes the mind redundant. For Baudrillard, this fragmentation can equally be observed in the realm of art. As art has become more and more integrated with daily 
banalities, the separation between life and art has become increasingly blurred.

This blurring of life and art occupies a central place in the work of American painter and writer Frances Stark. More recently, her work has focused on the content of personal online chats. Notably, her video works, My Best Thing (2011), Osservate, leggete con me (2012), and Nothing Is Enough (2012), explore, discuss, and shed light on the possibilities of intimate encounters online. In My Best Thing (2011), for example, Stark documents the conversations between herself and two young Italian men, both of whom she was having an online sexual relationship with at the time (Fig. 9.1).

In the video, the artist transforms the Skype conversations between the speakers into a Playmobil cartoon through the means of text-to-speech Xtranormal animation software. Initially exhibited at the Venice Biennial in 2011, the video consists of nine soap opera-like episodes, each one lasting for no more than ten minutes. While the artist and the young men flirtatiously get to know each other via written conversations, the focus of their encounters mainly evolves around cam sex: "Want to see my best thing," asks the young Italian. "Sure," responds Stark (Stark, 2011). Soon afterward, however, their conversations move on to other topics

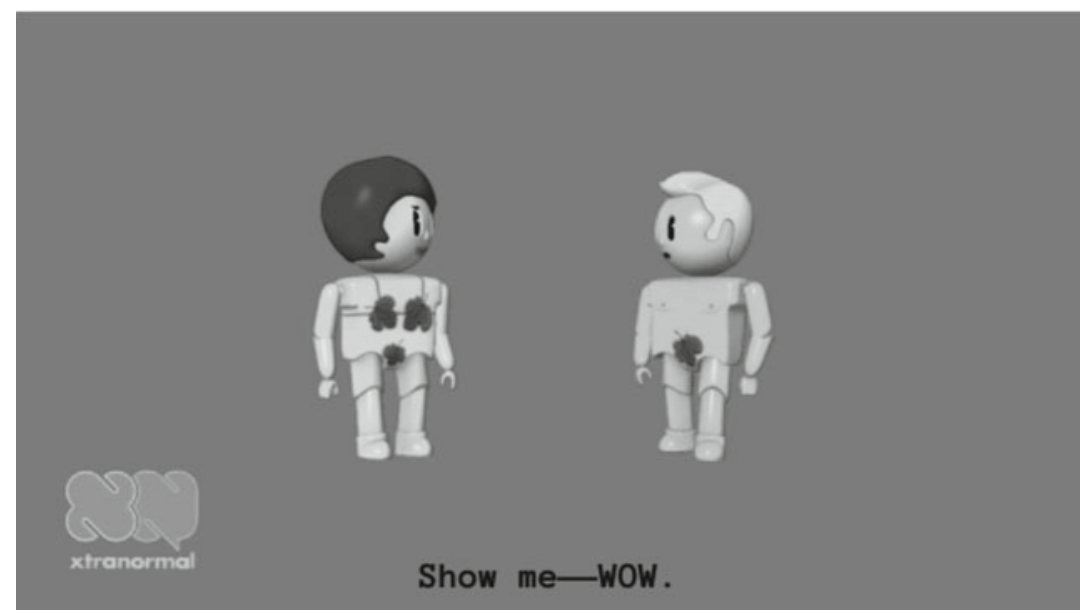

Fig. 9.1 Frances Stark: My Best Thing, 2011. Digital video, color, sound, lh $40 \mathrm{~min}$. (Courtesy the artist and Galerie Buchholz, Berlin/Cologne/New York) 
like film history, poetry, and Stark's artistic approach and participation at the Venice Biennial. In this work, Stark unites physically distant lovers in virtual space. In doing so, she distinguishes the actual from the virtual encounter between herself and her lovers. Stark later invites one of the men, Marcello, to come to Los Angeles for a collaboration; he later disappears after being run over by a police car and hospitalized during a protest in Italy. This failed attempt to enact a physical meeting compels Stark to include the messages and conversation topics exchanged with Marcello in her second virtual encounter, with the son of an Italian filmmaker.

Often, online relationships are underlined by the promise to meet up in real life, the ultimate realization of which is itself undetermined. As Marcello says at one point in My Best Thing, "Real is better" (Stark, 2011) This may conjure parallels with what the scholar Lauren Berlant (2011) has described as cruel optimism:

A relation of cruel optimism exists when something you desire is actually an obstacle to your flourishing. [These kinds of relations] become cruel only when the object that draws your attachment actively impedes the aim that brought you to it initially. (p. 23)

In this sense, Berlant defines cruel optimism as an unrealizable desire, which lays out its aims while simultaneously preventing one from achieving them. This might be a helpful framework for understanding online relationships, because while one is bound to the screen in order to maintain their existence in many cases this makes an actual encounter impossible. Additionally, the fantasy evolving around these relationships is hardly ever met. Consequently, online relationships have emancipated themselves from their physical promise to reunite and exist solely online.

In order to follow the continuous dialogue between Stark and her Italian lovers in My Best Thing (2011), the viewer is obliged to listen to the audio and simultaneously read the subtitles and summaries between each episode. The visual dimension of the virtual encounter, through a video Skype conversation, is limited. When the lovers reveal their bodies in order to have cam sex, the viewer can only see a close-up of the motionless faces of their animated stand-in characters, accompanied by a robotic "Mhmhmhmh." This type of textualization of the conversation's content adds a comical dimension to the work. However, the use of imagination within online communication is closely linked to the very condition in which people initiate intimate experiences, since there is no physical 
sexual interaction with another human being, but only with themselves: the participants act as separate entities, while paradoxically jointly experiencing an intimate encounter. This also brings us back to Steyerl's (2011) quest for a "live and lively" visible absence, which My Best Thing evokes by frustrating the viewer's excitement at the idea of promised intimate action. Nonetheless, the viewer is integrated into the intimacy taking place just out of view through the shared sentiment captured by the written word, which has itself become part of our daily communication. As Kitnick (2013) states:

Marshall McLuhan's famous dictum that 'media are extensions of man' may be right, but in Stark's hands the opposite is perhaps even more true: 'Man' is an extension of media. Text propels bodies. Where earlier feminism spoke of 'writing on the body', here we encounter writing as body. (p. 70)

Stark is not only commenting on McLuhan's notion of the extension of the corporal body through innovative technology (from his infamous text, The Medium Is the Message [1964]), but is also creating a new kind of body. Instead of representing the physical body, My Best Thing (2011) makes visible the complexities of virtual communication and underlines the independent modus operandi of its written element.

In Nothing Is Enough (2012), Stark combines chat messages from men around the globe with a musical piece by Marcello, the protagonist of My Best Thing. Over the course of approximately fifteen minutes, the melancholic sound of a piano accompanies black typed messages, which appear in the center of a white screen, changing from regular to italic font to represent the alternating writers of the conversation. The joining together of several conversations with changing chat partners highlights the complexities of virtual encounters today, which are underpinned by the urge to keep up with an ever-expanding global network. This is reflected in one of the conversations: "Nothing is enough - the internet changed our lives," types the conversation partner, to which Stark simply replies: "Yes." Along similar lines, the aforementioned Nancy Baym (2010) has extensively researched personal connections within the digital age, and suggests that the internet has given all of its users the possibility of forming relationships that transcend space. As the shared location has lost its status as a prerequisite for a first meeting, the range of potential partners has been expanded to a broader pool than at any previous point 
in history. Baym underlines the almost inconceivable opportunities that intermedial communication offers, broadening possible personal relationships ad infinitum - an observation that reflects the experience of Stark's mode of production of an ever-expanding socio-cultural network.

Nothing Is Enough (2012) is displayed in a darkened gallery space, inviting the viewer to sit down on two rows of wooden benches. Reminiscent of an ecclesiastical setting, this set-up guides the spectator's gaze toward the white screen. Instead of the lively, visualized conversation between two animated figures in My Best Thing (2011), here the spectator witnesses only the exchange of typed messages. Thus, in Nothing Is Enough, Stark's focus has deliberately shifted toward the written word. By joining two physically distant people literally communicating on the same page, the artist visualizes a shared moment through language. Both writers are communicating through similar technical tools and the shared English language. Despite its essential role, the medium of the written word is often undervalued in the post-digital age. As art critic Nancy Princenthal (2011) points out: "The Internet Age is widely understood as the apogee of image culture, but the medium in which we swim, buoyed by waves of chat, posts and tweets, seems increasingly to be the written word" (pp. 83-89).

Stark actively engages the use of language in all her video works. This is further evident in the three-channel installation Osservate, leggete con me (2012), translated into English as Look, Read with Me, where Stark juxtaposes a soundtrack of Mozart's Don Giovanni with text messages. Over the course of approximately 30 minutes the viewer may follow conversations between the artist and men across the globe, varying from sexual foreplay to more serious topics of conversation, such as job choices. On a black screen the conversation appears, now both parts in italic font, but on opposite sides. This ping-pong dialogic epitomizes how love in the twenty-first century might start. Even though Osservate, leggete con me addresses sexuality openly, the conversations sometimes stumble over private content. Stark not only unites the conversations between herself and her lovers, but additionally includes the audience. This flirty atmosphere is echoed not only in the conversations but also in the narrative of Mozart's Don Giovanni, in which a promiscuous Italian nobleman travels through Europe, seducing women. In Stark's case, her virtual sexual relationships with strangers were the beginning of an artistic contemplation that formed three video works. Nevertheless, the virtual meeting 
precludes any physical act. Instead of Don Giovanni's physical conquests, only an onanistic act of self-love takes its place.

\section{INTIMATE Bodies ONLINE}

In his book, Bodies in Code: Interfaces with Digital Media (2006), Mark Hansen investigates the status of bodies within cyberspace and, in turn, articulates a theory that goes against the grain of those that see the body in virtual reality as a detached form of being. Instead, he refers to the French psychoanalyst Jacques-Alain Miller's discussions of the role of the body in media environments, which "reverberate" with the "potential promise of second-generation virtual reality/mixed reality for rethinking culture through embodiment" (Hansen, 2006, p. 14). This concept is key for Hansen's understanding of the nature of cyberspace and computergenerated imagery (CGI) of humans. Opposed to an autonomous entity online, Hansen perceives these virtual modes of being as grounded in the physical body.

In the same way, through the utilization of the latest technological means, the practice of British artist Ed Atkins allows for an insight into future modes of embodiment online. In contrast to Stark, Atkins is part of a generation of digital natives, i.e. individuals who have grown up fully immersed within internet culture and its possible interfaces, from its advent in the late 1980s onward. Through the reproduction of life-like bodies using immaterial means, he provokes a dialogue about verisimilitude in virtual reality and the user's afterlife. Atkins's engineering of the interface-a shared boundary in computing, such as a screen-allows for an intimate encounter in the post-digital age precisely through this embodiment. First screened at Chisenhale Gallery, London, Atkins' Us Dead Talk Love (2012) is a two-channel video and surround-sound installation juxtaposed with collaged panels. Displayed on two angled screens was CGI of a human head reflecting on love, death, and intimacy over the course of approximately 40 minutes. The bodiless head-viewed from different angles-appeared consecutively on one or the other screen, or sometimes simultaneously on both, suggesting the juxtaposition of an interviewer and interviewee, of a speaker with its audience. Next to the $3 \mathrm{D}$ rendering of the talking head, snippets of black and white film, collaged photographs and detailed digitally rendered body parts were projected (Fig. 9.2). 


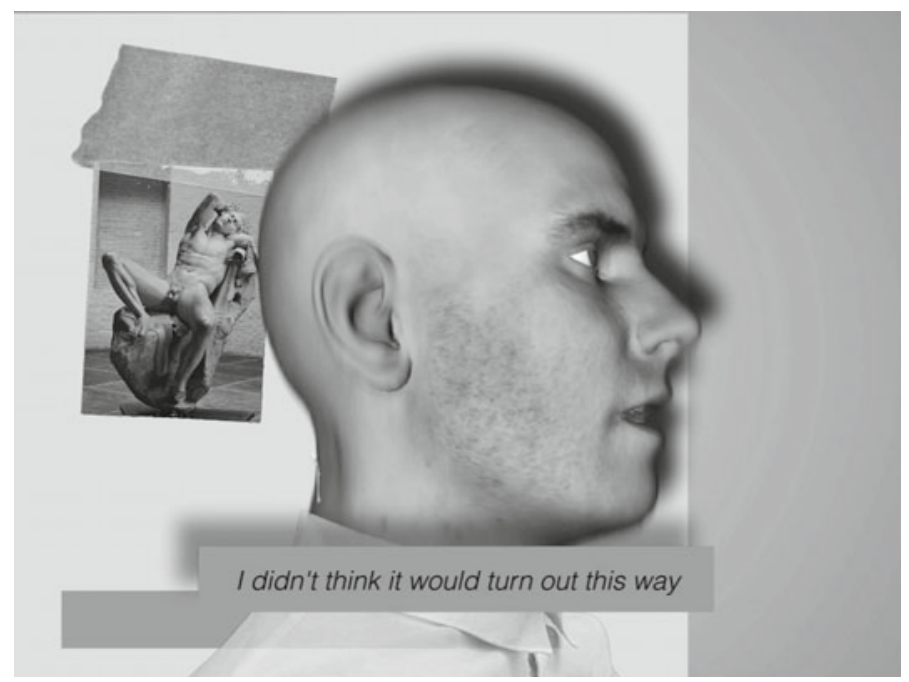

Fig. 9.2 Ed Atkins. Us Dead Talk Love, 2012. Two-channel video with sound, $37 \mathrm{~min} 24 \mathrm{sec}$ (Courtesy the artist, Cabinet Gallery, London, Galerie Isabella Bortolozzi, Berlin, Gladstone Gallery, New York and dépendance, Brussels)

In Us Dead Talk Love, multiple narratives are tied together into what Atkins describes as "a tragedy of love, intimacy, incoherence and eyelashes" (Atkins, 2012, para 1). At the beginning of the multimedia installation an off-screen voice mutters, "OK, again," functioning as an entry point. A few seconds later, a photograph of the Barberini Faun appears-a Greek marble statue from the second century BC embodying a drunken satyr in a sexual posture, overtly displaying his genitalsaccompanied by an ecclesiastical choir singing the word "Sorry." This is followed by the narrator's repeated recitation of the work's title, which simultaneously appears on both screens in black and white typed text.

An important narrative device in Us Dead Talk Love revolves around the eyelash, which appears as a convex dash on one of the screens. According to the CGI head's own words, it represents a "congress between the living and dead." He interprets the eyelash "not [as] a representation at all, but the real thing [...] the pronominal cell, as I, as I bedded down beneath the foreskin." These descriptions are closely linked to the condition of the main protagonist himself: more dead than alive, 
the bodiless head clings on to life through his outward appearance as a living human being. Nonetheless, his disembodied condition in turn emphasizes his lifeless state. Even though this image appears to be a human head, it is in fact digitally created. In his publication Faces, the Austrian art historian Hans Belting (2013) notes the paradoxical nature of digital faces:

A digital face as an image is a paradox, because it denies the old task of depiction and with the analogy to a real face it loses its historical reference. Cyberfaces occur in the history of the portrait as an elementary contradiction. They are not faces, but only mere interfaces between an infinite number of possible images whose circulation is enclosed to the outside, without bodies intervening. (p. 298)

This enclosed nature of the interface is pivotal for understanding $U s$ Dead Talk Love. The CGI of the human face is created through the means of digital technology, but which is in turn separated from any embodied reality. Evidently, a talking, bodiless head is physically impossible, and so is its effortless multiplication and fragmentation. Following Belting's statement, the CGI head is restricted to his virtual habitus and does not trespass into the physical sphere. This disembodied reality of a digitally rendered face, talking in a lively manner, is juxtaposed with the bodily reality of the audience. The drawings displayed at the back of the room enhance the paradox of disembodied reality and physical corporality permeating our society.

In this sense, then, the work creates an imitation of a human by digital means to evoke the notion of the post-human-a human striving to exceed his mortal limitations. This idea in turn recalls Baudrillard's (2001) seminal text "Simulacra and Simulations" from 1988, where he discusses the substitution of the real with the hyperreal. Such a substitution adds a degree of separation-highlighting one of the main issues in digital media environments - that by which the copy of a copy loses its original point of reference. Both concepts are crucial for an understanding of the hyperreal appearance of avatars in cyberspace.

In Us Dead Talk Love (2012), the narrator-the bodiless head-at one point begins to lip-synch to Tim Burton's 2007 adaptation of the love song "Johanna" from the musical Sweeney Todd: The Demon Barber of Fleet Street (1973). The head's "features purse and wince and wonder, in 
anticipation of and reaction to the song, as if gingerly trying out expressions for the first time" (Luna, 2014, p. 8). These infantile articulations may allude to the nativity of the digital rendering, a bodiless head who is getting accustomed to his surroundings. The lyrics of the song "Johanna" set up the crux of Us Dead Talk Love, namely the desire of two separated lovers to be together, a theme which reoccurs throughout the artwork. In the musical, the song is sung by Anthony Hope, a young sailor who wanders the streets of nineteenth-century London and notices a blonde girl at a window, trapped in her house, looking out at him longingly. It is love at first sight. Mesmerized by her beauty, Hope sings:

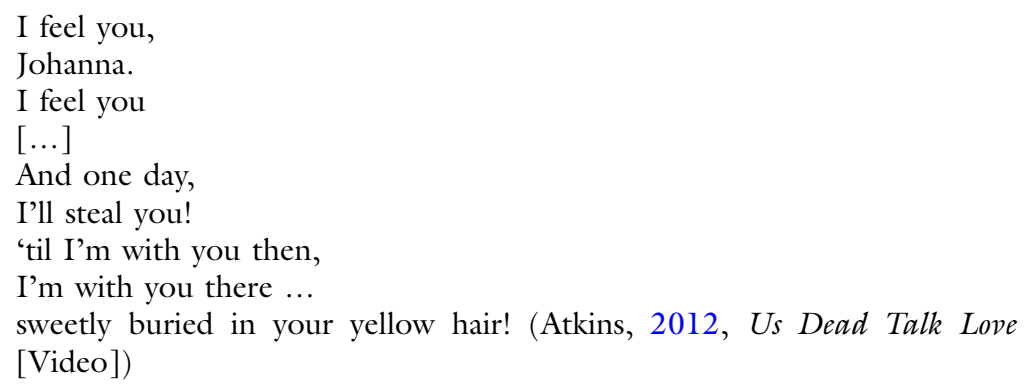

Even though the lovers are not physically united, Hope sings about his ability to feel close to his beloved. In Us Dead Talk Love, as the bodiless CGI head sings Hope's lyrics, a blond, male, computer-generated version of Johanna appears on the adjacent screen. Rather than a conversation between one head with itself, now the work displaces two lovers across separate screens. Even though the two avatars are situated in the virtual sphere, which knows no spatial or temporal limits, the physical separation of the two screens reinforces their distance, echoing that which separates Hope and Joanna, and enriching an understanding of the concept of unfulfilled romantic love.

Atkins himself refutes any understanding of CGI as a concrete material, and instead points to its potential to manifest desire. How then does $U s$ Dead Talk Love contribute to the notion of touch or corporeal closeness in the post-digital age? This is closely linked to Jacques Derrida's statement in On Touching-Jean Luc Nancy (2005), where he links the notion of touch to the French term "limitrophe"-something neighboring or near: "Touching, in any case, thus remains limitrophe; it touches what it does not touch; it does not touch; it abstains from touching on what it 
touches, and within the abstinence retaining it at the heart of its desire and need" (Derrida as cited in Nancy, 2005, p. 67).

This idea of touching without actually touching, and thus eternally perpetuating the desire to do so, is expressed in Us Dead Talk Love by the narrator longing for the touch of his lover-separated on neighboring on screens they cannot touch, which increases their desire. In contrast to the head's lonely pilgrimage from one screen to the other and the appearance of the back of his blond lover at the beginning of the work, he is longing to face and feel his beloved in the virtual realm, which is also highlighted by two hands touching. Atkins creates an intimate approach to the body through his use of high-definition imagery of the hyperrealistic human. Through the utilization of immersive sound and video, the audience is phenomenologically addressed and brought into the work's narrative. Its imagery, monologues, and written notes evolve around love, intimacy, and the desperate need to communicate. Thus, the desire to touch, love, and, be together reoccurs in an active questioning of the physical restraints and future possibilities of embodiment in the hyperreality of the digital space. The French philosopher Jean Luc Nancy provides a forward-looking glimpse of desire and bodies in his publication Corpus:

This areal body, this video-body, this clear-screen-body, is the glorious materiality of what is coming. What is coming happens to a presence that hasn't taken place, and won't take place elsewhere, and is neither present, nor representable, outside of what is coming. Thus, the coming itself never ends, it goes as it comes, it's a coming-and-going, a rhythm of bodies being born, dying, open, closed, delighting, suffering, being touched, swerving. Glory is rhythm, or the plasticity of this presence - local, necessarily local. (Nancy, 2008, p. 65)

Nancy's concept of the body is one that transgresses. It is in a state of constant coming and going and does not need defining signifiers. Consequently, it is freed from its bodily and corporeal restrictions and equipped for the post-digital condition. This desire for bodies to meet and unite is an ongoing point of contemplation in the work of Frances Starks and Ed Atkins. Even if physicality is transferred to the digital realm, the urge for physical touch remains the ultimate quest.

Nevertheless, the concept of sharing and shared experience may offer an extension to this displacement of physical intimacy in the post-digital 
era. This is addressed by Lauren Berlant (2000), who links intimacy to a shared narrative that goes beyond one's own experience:

To intimate is to communicate with the sparest of signs and gestures, and at its root intimacy has the quality of eloquence and brevity, but intimacy also involves an aspiration for a narrative about something shared, a story about both oneself and others that will turn out a particular way. (p. 1)

"A narrative about something shared" (p. 1) is potentially harder to grasp than the obvious phenomenological dimension (or lack thereof) to virtual intimacy. If, as Berlant states, intimacy is possible through simple signs and gestures, or a shared story uniting the self and others, accessible to everybody, this may form the basis of and alternative dialogue about intimacy in the post-digital age that pivots around shared strategies of communication rather than (virtual) corporeality. Therefore, intimacy may not necessarily depend on physical touch, but could also be embedded through the simple gesture of swiping the screen. Staying in touch digitally, even though rooted in our daily communication, can make way for intimacy through digital means only.

\section{Live AND Lively ABsence}

As described earlier, the concept of touch is closely linked with what Hito Steyerl (2011) calls a "live and lively absence" (p. 58). When contemporary bodies are transferred into the virtual realm, they inhabit a sphere of hyperreality, as a "reference of a reference" they lose contact with their original human source, which in turn raises questions about their authenticity. The visual image of a tablet evokes a more mundane notion of touch: interacting with other people in virtuality. Touch may also transgress into virtuality and may be experienced through signs and gestures-for example, the swiping of a screen. In this way, the body is not limited to its phenomenological origin as corporeal body. The notion of touch is extended through a shared narrative or sentiment. Therefore, artistic practices such as the ones discussed in this chapter, and others, not only highlight the changing nature of intimacy in the post-digital age, but also create new ways to be intimate.

Even when touch is dispersed, it is grounded in the physicality of bodies; the notion of corporeal touch remains vital for any encounter within interpersonal relations permeated by digital technology. However, 
once transferred into the virtual realm, intimacy and touch can be experienced through a perpetually evolving process. New technologies further the possibilities of virtual encounters, expanding the formats by which we stay in touch. Shared narratives or sentiments can initiate online intimacies, which lie beyond the phenomenological realm. The urge for the physical touch of another human being remains at the core of our understanding of intimacy.

As Stark's video works articulate the shared intimacy created in online chat rooms, Juuso Tervo rethinks the role of politics, love and intimacy as they relate to education, in the pamphlet Intimacy with a Stranger: Art, Education and the (Possible) Politics of Love (2019). In pedagogical terms, the intimacy of loving and learning is among things grounded in a "relation to oneself that requires self-knowledge, selfreflectivity, and continuous self-adjustment" (p. 23). Similarly, as in the frustration that is evoked in the works of art described above, which arises through engaging with intimacy online, art educators are nowadays confronted with the "uncertainty of our precarious labor [which is met by] aestheticiz[ing] it, and turn[ing] it into a lifestyle from which creativity and innovation emerge" (p. 28). Here, this frustration and the potentialities that lie within it can make way for new concepts of art education that engage in the integration of love and intimacies of art.

\section{Digital Intimacies in Art Education}

In times of increased digitalization, conditions for art education are facing new challenges, in turn exacerbated by those of the pandemic, Covid-19. Limited and restricted forms of cooperation and encounter make urgent the need for new ways of discussing and mediating art. Additionally, art education has to integrate the digital dimension into its ways of operating, and at the same time find ways of being together while apart. How is it possible to convey pedagogical intimacy in a time when online communication has become a key tool of education? How can groups interact with each other and experience a virtual situation as intimately as a physical one?

soppa\&bleck are a collaborative duo who have, in recent years, established the inclusion of the digital dimension into their educational workshops, through concepts that focus on digital feminist strategies situated between art and activism. An example of this is a form of mediation 
that takes place both online and offline, where, as they have said, "digitality should not be a mediation tool, but its condition" (Bleck \& Soppa, 2019 , para 2). In this way, the physical commonality of communication or use of a shared space for education is transferred to the digital realm, in turn engaging with the incursion of the digital in our everyday lives and therefore our intimate relationships.

In 2018, different formats of soppa\&bleck's workshop "Playinbetween" were presented during the "dgtl fmnm festival" held in Dresden, Germany. Through these formats soppa\&bleck were attempting to engage the audience in various ways, some of whom were physically present and others who were online, bringing both together through a playful approach. One example of the online/offline strategy was the embedded Karaoke Pool, which enabled all participants to engage via their smartphones. With the help of a moderator, a wish list of songs was created, which were then recorded without the need for physical presence. In this way, a unique community was formed in parallel to that of the festival-taking the interaction and engagement online.

A later workshop developed in 2019 for the next iteration of the "dgtl fmnm festival" entitled "what we can do online that we can't do alone" investigated the constitution of assemblies from various different angles and viewpoints. Together with collaborators, soppa\&bleck initiated several parts of their program online, prior to the start of the physical festival. The "Telegram Think Tank with Omsk Social Club," for example, functioned as a think tank for this broader, online audience to collect ideas about digital and physical connections. In this way, an expandable archive was formed and made accessible to all participants. Following from this, chats were sent via the messenger telegram during the physical festival and introduced online communication as the group's preferred mode of communication. When the conversation was returned to the physical room, underlying power relations became more evident. Online communication tools thus presented a way in which to form a non-hierarchical community through its democratized platforms.

The Covid-19 pandemic has revealed another dimension to the value of online communication. Many approaches to the digital in art education now seem mainstream. In their latest project, "Outside Office we can't go back to normal" (2020), soppa\&bleck consider the conditions of working together during the pandemic and what they could contribute to the process. Through a digital park walk in a joint chat, their audience met up online and participants were able to walk together through a park 
(or a living room, etc.) online. In this way, there was an interaction that was experienced online, and could then be experienced again afterward in the physical world. The post-digital therefore expands the capacities and possibilities of touch as applied to art and education. In order to stay in touch and to connect with topics around intimacy we "require attachment and commitment with the unknown that art always work[ed] with; an attachment akin to an intimacy with a stranger" (Tervo, 2019, p. 18).

\section{New Intimates}

In times that are experiencing the emergence of new forms of digital intimacy, physical presence might appear to be less and less a component of everyday life. More often we stay in touch with each other via online communication platforms, rather than through face-to-face conversations. With the development of the Covid-19 pandemic, virtual communication tools have become lifelines for millions of people across the globe. Our growing physical distance has led to a discourse that condemns screens and digital communication as a buffer for, or barrier, to real touch.

However, this neglects the possibilities that this new socially distanced status quo offers in regard to intimacies within the digital. In post-digital art and education, new modes of intimacy are grounded in forms of online communication that imply the potential of the phenomenological body, but also engage independently from these reductive connotations. Both integral tools of communication in the post-digital, education and art are already shaping how we perceive content and interact with each other. Through the use of language, and the live and lively absence of the physical body, new intimacies are enabled that are paradoxically grounded in this displaced corporeality. Intimacy as a brevity and common ground, or the sparest of signs, enables an approach toward art and the digital that foregrounds shared narratives and experiences.

New intimates are intimacies that are created online, ones that connect us with each other and in an ever more physical sense with ourselves. These intimacies create moments of concentration and focus, and promote an exchange of content with others. New intimates draw us back to our own bodies through forming new allies and communities which each other. They are not competing with the physical world but have become part of this very world. They are not new, but yet inform and expand something that has always been a part of us. By incorporating 
digital dimensions, new intimacies have made their way from the physical to the digital and back again, to bodies and our everyday lives.

\section{Note}

1. In German: „Wir berühren nur noch touch screens. Dadurch denke ich, verlernen wir es möglicherweise, den anderen zu streicheln (lacht). Ich denke, dass wir uns heute zu sehr in uns hineinfressen. Und dass wir nicht auf den anderen hin gerichtet sind. Und die Depression kommt daher, dass wir in uns in uns hineinfressen. Und der Eros ist eine Erfahrung, dass ich aus mir herausgerissen werde, durch den anderen."

\section{REFERENCES}

Atkins, E. (2012). Us dead talk love. Two-channel HD video, colour and sound, $34: 24 \mathrm{~min}$.

Baudrillard, J. (2001). Simulacra and simulations. In M. Poster (Ed.), Jean Baudrillard: Selected writings (pp. 169-187). Polity Press.

Baudrillard, J. (2009). Why hasn't everything already disappeared? (C. Turner, Trans.). Seagull Books.

Baym, K. N. (2010). Personal connections in the digital age: Digital media and society series. Polity Press.

Belting, H. (2013). Faces: Eine Geschichte des Gesichtes (P. Kommoss, Trans.). C.H. Beck

Berlant, L. (2011). Cruel optimism. Duke University Press.

Berlant, L. (2000). Intimacy. University of Chicago Press.

Bleck, S., \& Soppa, J. (2019). Volkswagen Fellowship zum Dritten mal vergeben! https://www.staedtische-galerie-wolfsburg.de/aktuelles/23-09-2019/.

Chisenhale Gallery. (2012). Ed Atkins: Us dead talk love. https://chisenhale.org. uk/archive/exhibitions/index.php?id=125.

Derrida, J. (2005). On touching-Jean Luc-Nancy (C. Irizarry, Trans.). Stanford University Press.

Hansen, M. B. N. (2006). Bodies in code: Interfaces with digital media. Routledge.

Kapitale Berlin. (2012, December 15). Byung-Chul Han-aspekte [video]. YouTube. https://www.youtube.com/watch?v=GJr-AIbnZEg.

Kitnick, Alex (2013). Text after Text. Parkett, 93, 66-71.

Luna, J. (2014). Against immortality as such. In B. Ruf (Ed.), Ed Atkins (pp. 814). JEP Ridinger. 
McHuge, Gene (2014). The context of the digital: A brief inquiry into online relationships. You are here: Art after the internet, (pp. 29-34). Manchester: Cornerhouse.

Nancy, J.-L. (2008). Corpus (R. A. Rand, Trans.). Fordham University Press.

Princenthal, N. (2011). Margin trading: Frances Stark. Art in America, 99(1), 82-89.

Sondheim, S. (2008). Sweeney Todd: The demon barber of fleet street. Sound recording.

Stark, F. (2011). My best thing. Single-channel digital video, colour and sound, $99 \mathrm{~min}$.

Stark, F. (2012). Nothing is enough. Single-channel digital video, black and white and sound, $14 \mathrm{~min}$.

Stark, F. (2012). Osservate, leggete con me. 3-channel digital video, colour and sound, $29.34 \mathrm{~min}$.

Steyerl, H. (2011). Epistolary affect and romance scams: Letter from an unknown woman*. October, 138, 57-69.

Tervo, J. (2019). Intimacy with a stranger: Art, education and the (possible) politics of love. Universitätsdruckerei.

Open Access This chapter is licensed under the terms of the Creative Commons Attribution 4.0 International License (http://creativecommons.org/licenses/ by $/ 4.0 /$ ), which permits use, sharing, adaptation, distribution and reproduction in any medium or format, as long as you give appropriate credit to the original author(s) and the source, provide a link to the Creative Commons license and indicate if changes were made.

The images or other third party material in this chapter are included in the chapter's Creative Commons license, unless indicated otherwise in a credit line to the material. If material is not included in the chapter's Creative Commons license and your intended use is not permitted by statutory regulation or exceeds the permitted use, you will need to obtain permission directly from the copyright holder.

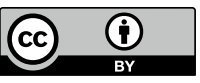

